\title{
Passive Transfer of Immunoglobulin G and Preweaning Health in Holstein Calves Fed a Commercial Colostrum Replacer
}

\author{
H. Swan, ${ }^{*}$ S. Godden, ${ }^{* 1}$ R. Bey, $†$ S. Wells, ${ }^{*}$ J. Fetrow, ${ }^{*}$ and H. Chester-Jonesł \\ *Department of Veterinary Population Medicine, \\ †Department of Veterinary and Biomedical Sciences, and \\ ‡Department of Animal Science, University of Minnesota, St. Paul 55108
}

\begin{abstract}
The objective of this study was to describe passive transfer of IgG and preweaning health in newborn calves fed a commercially available plasma-derived colostrum replacement (CR) product or maternal colostrum (MC). Twelve commercial Holstein dairy farms enrolled singleton newborn heifer calves to be fed fresh MC ( $\mathrm{n}=239$ calves) or one dose of CR containing 125 $\mathrm{g}$ of Ig ( $\mathrm{n}=218$ calves) as the first colostrum feeding. For 7 of these farms that routinely provided a second feeding of $1.9 \mathrm{~L}$ of $\mathrm{MC}$ to their calves 8 to $12 \mathrm{~h}$ after the first colostrum feeding, calves assigned to the CR treatment group were offered a second feeding consisting of $1.9 \mathrm{~L}$ of commercial milk replacer supplemented with one dose of a commercially available plasma-derived colostrum supplement, containing $45 \mathrm{~g}$ of Ig per dose, 8 to $12 \mathrm{~h}$ after the first colostrum feeding. A blood sample was collected from all calves between 1 to $8 \mathrm{~d}$ of age for serum IgG and total protein (TP) determination, and records of all treatment and mortality events were collected until weaning. Serum IgG and TP concentrations were significantly higher in calves fed $\mathrm{MC}(\mathrm{IgG}=14.8 \pm 7.0 \mathrm{mg} / \mathrm{mL} ; \mathrm{TP}=5.5 \pm 0.7 \mathrm{~g} / \mathrm{dL})$ compared with calves fed CR (IgG = $5.8 \pm 3.2 \mathrm{mg} / \mathrm{mL}$; $\mathrm{TP}=4.6 \pm 0.5 \mathrm{~g} / \mathrm{dL}$ ). The proportion of calves with failure of passive transfer (serum IgG $<10.0 \mathrm{mg} / \mathrm{mL}$ ) was 28.0 and $93.1 \%$ in the MC and CR treatment groups, respectively. Though a trend was present, the proportion of calves treated for illness was not statistically different for calves fed MC (51.9\%) vs. CR (59.6\%). Total number of days treated per calf $(\mathrm{MC}=1.7$; $\mathrm{CR}=$ $2.0)$, treatment costs per calf $(\mathrm{MC}=\$ 10.84$; $\mathrm{CR}=$ $\$ 11.88$ ), and proportion of calves dying ( $\mathrm{MC}=10.0 \%$; $\mathrm{CR}=12.4 \%$ ) was not different between the 2 colostrum treatment groups. The mean serum total protein concentration predictive of successful passive transfer (serum $\operatorname{IgG}=10 \mathrm{mg} / \mathrm{mL}$ ) was $5.0 \mathrm{~g} / \mathrm{dL}$ in calves fed $\mathrm{MC}$
\end{abstract}

Received February 28, 2007.

Accepted April 18, 2007.

${ }^{1}$ Corresponding author: godde002@umn.edu or CR. Long-term follow-up of these calves (to maturity) is ongoing to describe the effects of feeding CR on longevity, productivity, risk for Johne's disease, and economics.

Key words: colostrum replacement, failure of passive transfer, immunoglobulin

\section{INTRODUCTION}

Failure of the neonatal calf to absorb adequate colostral immunoglobulins into circulation within the first $24 \mathrm{~h}$ of life results in failure of passive transfer (FPT; serum IgG $<10.0 \mathrm{mg} / \mathrm{mL}$ ), resulting in increased risk for neonatal disease and mortality and a negative effect on the future health, longevity and performance in the herd (DeNise et al., 1989; Davis and Drackley, 1998; Faber et al., 2005). The National Dairy Heifer Evaluation Project identified colostrum management as an important opportunity area for the dairy industry when it reported that over $40 \%$ of dairy heifers failed to reach adequate serum IgG levels of $\geq 10 \mathrm{mg} / \mathrm{mL}$ between 1 and $2 \mathrm{~d}$ of age (NAHMS, 1993).

Despite the important nutritional and immune benefits provided, the first colostrum feeding also offers the calf one of the first opportunities for exposure to pathogens such as Escherichia coli, Salmonella spp., Mycoplasma spp., and Mycobacterium avium ssp. paratuberculosis (MAP), the agent causing Johne's disease. Many of these organisms could be shed directly from the glands of infected cows or could result from contamination with infective feces due to improper colostrum harvest, handling, or storage procedures (Streeter et al., 1995; Stewart et al., 2005). Early exposure to these pathogens represents significant animal health and economic issues for calves and producers, respectively. As well, some of these pathogens are of public health concern should they eventually enter the food chain.

Commercial colostrum replacement $(\mathbf{C R})$ products may provide a viable alternative to feeding maternal colostrum and could serve as a very effective management tool to prevent colostral disease transmission. Colostrum replacement products contain bovine Ig that 
is typically lacteal-derived or plasma-derived and are intended to completely replace maternal colostrum feedings. The CR should contain a minimum of $100 \mathrm{~g}$ of IgG per dose, the minimum recommended dose in order for calves to receive to attain a predicted final serum IgG >10 mg/mL (Quigley et al., 2001, 2002), and must also contain a nutrient pack that provides a source of protein, energy, vitamins, and minerals similar to levels found in maternal colostrum.

If $\mathrm{CR}$ products prove to be an effective substitute for maternal colostrum while potentially reducing disease transmission, they could serve as one critical control point for preventing the transmission of several infectious diseases, including MAP. Previous studies published in the peer-reviewed literature have reported on passive transfer of IgG in calves fed some CR products (Quigley et al., 2001, 2002; Jones et al., 2004; Foster et al., 2006). However, most previous $\mathrm{CR}$ studies include at least one or more of the following limitations: 1) fed a CR test product or purified Ig concentrate instead of a CR product that is commercially available to producers, 2) performed study in a research setting instead of on commercial dairy farms, or 3) did not enroll enough calves to allow the investigator to adequately evaluate the effect of feeding a CR on calf health or economic outcomes. As such, questions remain as to the ability of commercial CR products to adequately replace high quality clean maternal colostrum. For example, producers and veterinarians question if the total mass and appropriate spectrum of antigen-specific antibodies found in commercial CR products will adequately protect calves against farm-specific pathogen. Furthermore, $\mathrm{CR}$ products presumably will not contain viable white blood cells and possibly other protective nonspecific immune factors (e.g., cytokines, growth factors, lactoferrin) that are found in maternal colostrum (Reiter, 1977; Le Jan, 1996; Davis and Drackley, 1998). The potential impact of these differences on calf health has not been studied.

The short-term objective of this study (to be reported here) was to describe serum IgG levels, serum total protein levels (TP), preweaning morbidity risk, preweaning mortality risk, and preweaning treatment costs for commercial dairy calves fed maternal colostrum (MC) or a commercially available plasma-derived CR product (Acquire, American Protein Corporation, Ames, IA). Additionally, the paper will describe the relationship observed between serum TP and IgG measures in calves fed CR or MC. The long-term objective of this study (to be described after animals reach maturity) is to evaluate the effects of feeding commercial CR product on risk for Johne's disease transmission, longevity, productivity, and economics in commercial dairy herds.

\section{MATERIALS AND METHODS}

\section{Study Herds}

Twelve commercial Holstein dairy herds in Eastern Minnesota and Western Wisconsin participated in the study based on their ability and willingness to comply with the study protocols. Mean (range) herd size and rolling herd average was 650 (190 to 1,550) milking cows and $11,539 \mathrm{~kg}(9,761$ to 13,620$)$ of milk, respectively. Six of the 12 herds raised their calves on-site, whereas the remaining 6 producers relocated calves at 1 to $3 \mathrm{~d}$ of age to 1 of 2 professional heifer grower operations. Prior to beginning the study, all producers completed a survey describing their routine colostrum management program, calf housing, and general herd information (Table 1).

\section{Calf Enrollment}

Calf enrollment and data collection occurred between July and October of 2003. Newborn singleton heifer calves were removed from the dam before suckling and systematically assigned (every other calf) into 1 of 2 colostrum treatment groups: the control group received nonpooled fresh MC originating usually from the dam, though in some instances, refrigerated fresh colostrum from other dams might be fed if insufficient colostrum was available from the dam. The treatment group received one dose of a commercially available plasmaderived CR product (Acquire, American Protein Corporation, Ames, IA). The CR contained $125 \mathrm{~g}$ of Ig per dose and was mixed with $2 \mathrm{~L}$ of warm water according to package directions prior to feeding. The other components of each farm's colostrum management program remained unchanged during the study (e.g., time to first feeding, volume fed at first feeding, method of feeding: tube or bottle, and whether a second colostrum feeding was provided). Eleven of the 12 farms fed $3.8 \mathrm{~L}$ of MC at the first feeding, whereas 1 of the 12 farms (farm 9) fed only $1.9 \mathrm{~L}$ of $\mathrm{MC}$ at first feeding. For 5 farms that routinely provided only one colostrum feeding, all calves were fed a commercial milk replacer after the first colostrum feeding. For 7 farms that routinely provided a second feeding of $1.9 \mathrm{~L}$ of $\mathrm{MC}$ to their calves 8 to $12 \mathrm{~h}$ after the first colostrum feeding, calves assigned to the CR treatment group were offered a second feeding consisting of $1.9 \mathrm{~L}$ of commercial milk replacer supplemented with one dose of a commercially available plasma-derived colostrum supplement (CS; Lifeline American Protein Corporation, Ames, IA) 8 to $12 \mathrm{~h}$ after the first colostrum feeding. The CS contained $45 \mathrm{~g}$ of Ig per dose. The CS product was derived from the same original source as the CR product used in this study. On all farms, calves in both colostrum treatment groups 
Table 1. Description of colostrum and calf management practices on 12 study farms

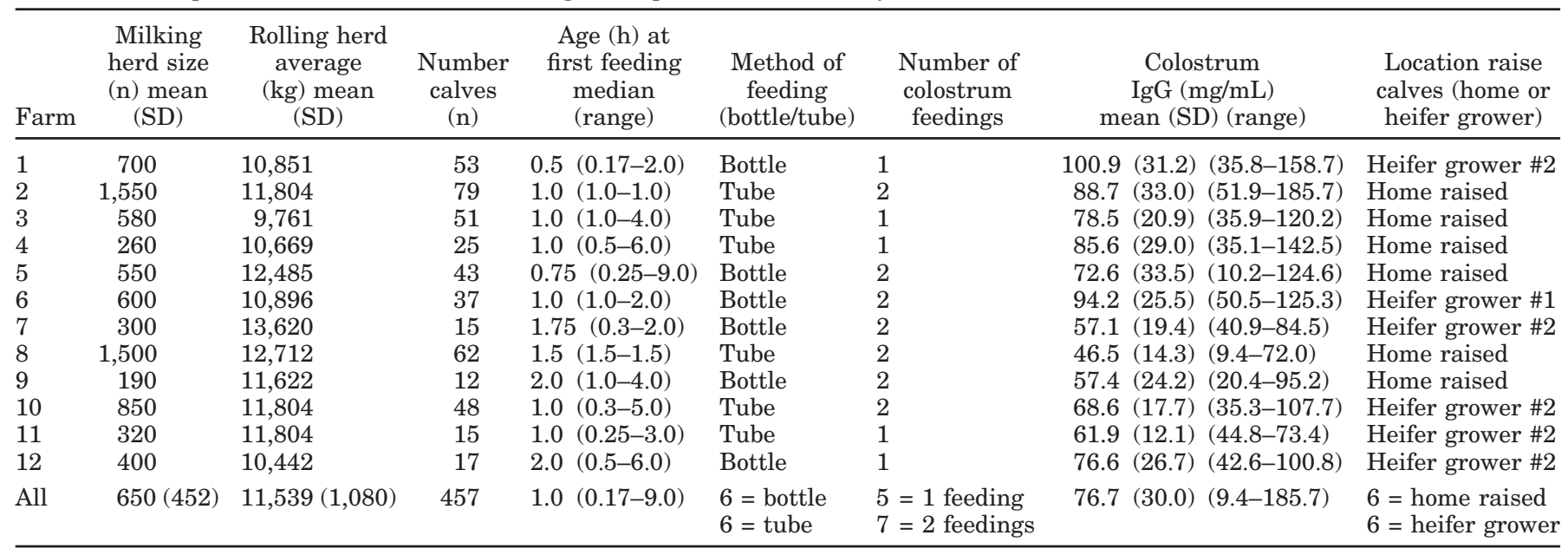

were fed commercial milk replacer, free choice pelleted calf starter diets, and free choice water until being weaned by $56 \mathrm{~d}$ of age.

\section{Records and Sample Collection}

Upon enrollment, the producer recorded the calf ID, dam ID, birth date, calf gender, number of calves (singleton or twin), calving difficulty $(1=$ unassisted or very easy pull; $2=$ moderate assistance required; $3=$ difficult pull), the colostrum treatment group assigned (MC or $\mathrm{CR}$ ), and age at first feeding (hr). Paired $20 \mathrm{~mL}$ samples of $\mathrm{MC}$ was collected into a sterile plastic sample tube immediately prior to feeding each MC calf, labeled with the date, calf ID, farm ID, and then frozen. The producer or the associated professional heifer grower recorded all treatment events including the dates treated, the producer-diagnosed disease syndrome (scours, respiratory, or other), the actual treatment provided (drugs used), and the total number of days treated prior to weaning. Additionally, all mortality events were recorded, including date of death and producer-diagnosed disease problem.

Study technicians visited each farm on a weekly schedule to collect calf enrollment, treatment and death records plus frozen samples of colostrum fed to the MC calves. Additionally, technicians collected a blood sample from all study calves once between $24 \mathrm{~h}$ and $8 \mathrm{~d}$ of age. The $8-\mathrm{mL}$ venous blood sample was collected via the jugular vein into a $10-\mathrm{mL}$ Vacutainer serum collection tube. All blood samples and frozen colostrum samples were transported on ice to the Veterinary Diagnostic Laboratory at the University of Minnesota for analysis.

\section{Sample Analysis}

Colostrum samples were thawed to room temperature and then underwent routine bacterial culture to determine total bacteria counts. The colostrum samples also underwent testing to determine colostral total IgG concentration $(\mathrm{mg} / \mathrm{mL})$ using a turbidometric-immunoassay (TIA; Instrument: Olympus AU400e, Olympus America Inc., Melville, NY; Reagents: Midland Bioproducts Corp., Boone, IA). The TIA is a highly sensitive automated lateral-flow immunoassay that directly measures turbidity of the antigen-antibody complex, producing accurate IgG measures as compared with the more time-consuming and labor intensive radial immunodifussion method (Etzel et al., 1997; McVicker et al., 2002).

Frozen colostrum samples were also transported, on ice packs, to the USDA, ARS, National Animal Disease Center in Ames, IA, for analysis using a modified nested real-time PCR assay for the detection of MAP in colostrum using a previously described method (Stabel and Bannantine, 2005). These PCR results will determine whether calves in the MC group were, in fact, exposed to MAP in colostrum. The results of this testing are not reported in this paper because they do not relate to the outcome objectives of the current study. However, they will be reported in a future manuscript that evaluates the effect of colostrum treatment group (MC vs. CR) on risk for infection with MAP in the adult animals.

Blood samples were refrigerated overnight to allow clot formation, and then centrifuged to separate the serum from the clot. Serum TP $(\mathrm{mg} / \mathrm{dL})$ values were determined using a handheld refractometer. Paired serum samples were frozen and then submitted to the Veterinary Diagnostic Laboratory to evaluate the IgG $(\mathrm{mg} / \mathrm{mL})$ concentration using a TIA. 
An interlab comparison of paired sample results showed excellent agreement for colostrum and serum IgG test results (compared with colostrum and serum results from Midland Bioproducts Corp., Boone, IA, and with serum results from American Protein Corporation, Ames, IA).

\section{Statistical Analysis}

Descriptive statistics were produced to describe colostrum IgG concentration $(\mathrm{mg} / \mathrm{mL})$, age at first feeding (hr), serum IgG $(\mathrm{mg} / \mathrm{mL})$, and TP $(\mathrm{g} / \mathrm{dL})$ concentrations between 1 to $8 \mathrm{~d}$ of age, proportion of calves with FPT (defined as serum IgG $<10.0 \mathrm{mg} / \mathrm{mL}$ ), and preweaning health indicators including proportion of preweaned calves that died, proportion of preweaned calves that were treated, number of days treated, and total preweaning treatment costs. Treatment costs were estimated using each farm's most commonly used disease treatment protocol for respiratory disease, scours, and other diseases (included bloat, off feed, and fever of nonspecified origin). The total costs for each disease considered labor estimates for diagnosis, treatment and record keeping activities, drug costs, supply costs (e.g., syringes and needles), and number of days treated.

Multivariate linear regression analysis (PROC MIXED in SAS, version 9.1) was used to describe the relationship between the explanatory variable of interest, colostrum treatment group (MC or $\mathrm{CR}$ ), and each of the following continuous dependent variables: serum IgG $(\mathrm{mg} / \mathrm{mL})$, serum TP $(\mathrm{g} / \mathrm{dL})$, preweaning total days treated $(\mathrm{d} / \mathrm{calf})$, and preweaning treatment costs $(\$ /$ calf).

Chi-squared analysis and then multivariate logistic regression analysis (PROC GENMOD in SAS) was used to describe the relationship between the explanatory variable of interest, colostrum treatment group ( $\mathrm{MC}$ or $\mathrm{CR}$ ) and each of the following categorical dependent variables: risk for treatment prior to weaning, risk for death prior to weaning, and risk for FPT (serum IgG < $10.0 \mathrm{mg} / \mathrm{mL}$ ). Proportional hazard regression analysis (PHREG in SAS) was also used to describe the relationship between colostrum treatment group and the survival hazard function for days to treatment or days to death (censoring occurred at $57 \mathrm{~d}$ of age).

In all regression models previously described, the herd of origin was controlled for as a random effect. Furthermore, all models offered to control for additional covariates in the model equation including age at first feeding (hr), number of colostrum feedings provided (1 or 2), day of age at blood sample collection, and calving ease score $(1,2$, or 3$)$. However, none of these covariates were found to be significant $(P>0.05)$ and so were ultimately removed from the final models using a backwards stepwise elimination process.

To examine the relationship between serum IgG and serum TP measures, a Pearson correlation coefficient was first calculated and then a linear regression model used to estimate the relationship between serum TP (dependent variable) and serum IgG (explanatory variable). This model offered an interaction term between colostrum treatment group $(\mathrm{MC}$ or $\mathrm{CR}) \times$ serum $\mathrm{IgG}$, and controlled for herd as a random effect.

\section{RESULTS}

The MC and CR study groups contained 239 and 218 heifer calves, respectively. This slight underenrollment of CR calves was attributed to the fact that weekend staff on some dairies occasionally forgot that a trial was in progress and so fed only MC. The mean ( $\pm \mathrm{SD}$; range) colostral IgG concentration for colostrum fed to MC calves at first feeding was $76.7( \pm 30.0 ; 46.5$ to 100.9$)$ $\mathrm{mg} / \mathrm{mL}$ (Table 1 ). The median age at first feeding for all calves was $1 \mathrm{~h}(0.17$ to $9.0 \mathrm{~h}$ ). However, it was interesting to note that calves fed CR had a significantly shorter interval $(P=0.0016)$ from birth to first feeding $(1.26 \mathrm{~h})$ than calves fed MC $(1.50 \mathrm{~h})$. This may be a reflection of the ease and convenience of mixing and feeding the CR product, compared with the increased time required to collect $\mathrm{MC}$ from the dam or to warm stored fresh MC.

The mean total plate count (TPC) and total coliform count (TCC; $\log _{10} \mathrm{cfu} / \mathrm{mL}$ ) for colostrum fed to the MC group was $8.21( \pm 1.62 ; 1.86$ to 11.02$)$ and $6.44( \pm 1.82$; 0 to 9.48 ), respectively. The geometric mean for the TPC and TCC for the MC colostrum was 16.1 million and 2.7 million $\mathrm{cfu} / \mathrm{mL}$, respectively. Although not the focus of this paper, it should be noted that these colostral bacteria counts are far in excess of the 100,000 cfu/ $\mathrm{mL}$ of TPC and $10,000 \mathrm{cfu} / \mathrm{mL}$ of TCC that are the current industry-recommended maximums for bacterial contamination of colostrum, indicating that the study farms had a significant opportunity to improve colostrum cleanliness (McGuirk and Collins, 2004). Serum IgG concentrations were not different, within either colostrum treatment group, for herds feeding only one colostrum feeding vs. for herds feeding 2 colostrum feedings. The day of blood sample collection (1 to 8) was not associated with serum IgG or serum TP measures.

The mean serum IgG concentration between 1-8 d of age was significantly higher for MC calves (14.8 \pm $7.0 \mathrm{mg} / \mathrm{mL}$ ) than for CR calves $(5.8 \pm 3.2 \mathrm{mg} / \mathrm{mL})$. Similarly, the mean serum TP concentration was significantly higher $(P<0.05)$ for MC calves $(5.5 \pm 0.7 \mathrm{~g} / \mathrm{dL})$ than for CR calves $(4.6 \pm 0.5 \mathrm{~g} / \mathrm{dL})$. The proportion of 
Table 2. Description of passive transfer of immunity and preweaning health parameters for calves fed maternal colostrum or a commercial colostrum replacement ${ }^{1}$

\begin{tabular}{|c|c|c|c|}
\hline Item & $\begin{array}{c}\text { Maternal } \\
\text { colostrum } \\
(\mathrm{n}=239)\end{array}$ & $\begin{array}{l}\text { Colostrum } \\
\text { replacer } \\
(\mathrm{n}=218)\end{array}$ & $P$-value \\
\hline$\underset{(\mathrm{mg} / \mathrm{mL})}{\text { Serum IgG }}$ & $\begin{array}{l}14.8(7.0) \\
(2.2 \text { to } 38.6)\end{array}$ & $\begin{array}{l}5.8(3.2) \\
(2.0 \text { to } 27.2)\end{array}$ & $<0.0001$ \\
\hline $\begin{array}{l}\text { Serum total protein } \\
(\mathrm{g} / \mathrm{dL})\end{array}$ & $\begin{array}{l}5.5(0.7) \\
(4.0 \text { to } 7.6)\end{array}$ & $\begin{array}{l}4.6(0.5) \\
(3.0 \text { to } 6.2)\end{array}$ & $<0.0001$ \\
\hline $\begin{array}{l}\text { Proportion with } \mathrm{FPT}^{2} \\
(\%)\end{array}$ & $\begin{array}{l}28.0 \\
(67 \text { of } 239)\end{array}$ & $\begin{array}{l}93.1 \\
(203 \text { of } 218)\end{array}$ & 0.0027 \\
\hline $\begin{array}{l}\text { Proportion treated } \\
(\%)\end{array}$ & $\begin{array}{l}51.9 \\
(124 \text { of } 239)\end{array}$ & $\begin{array}{l}59.6 \\
(130 \text { of } 218)\end{array}$ & 0.1552 \\
\hline $\begin{array}{l}\text { Proportion died } \\
(\%)\end{array}$ & $\begin{array}{l}10.0 \\
(24 \text { of } 239)\end{array}$ & $\begin{array}{l}12.4 \\
(27 \text { of } 218)\end{array}$ & 0.4317 \\
\hline $\begin{array}{l}\text { Total days treated } \\
\text { (d/calf) }\end{array}$ & $\begin{array}{l}1.7(2.3) \\
(0 \text { to } 10)\end{array}$ & $\begin{array}{l}2.0(2.5) \\
(0 \text { to } 12)\end{array}$ & 0.24 \\
\hline $\begin{array}{l}\text { Treatment costs } \\
(\$ / \text { calf })\end{array}$ & $\begin{array}{l}10.84(12.55) \\
(0 \text { to } 51.59)\end{array}$ & $\begin{array}{l}11.88(12.60) \\
(0 \text { to } 62.04)\end{array}$ & 0.31 \\
\hline
\end{tabular}

${ }^{1}$ Values reported $=$ mean $(\mathrm{SD})$ (range).

${ }^{2} \mathrm{FPT}=$ failure of passive transfer.

calves with FPT in the MC and CR treatment groups was 28 and $93 \%$, respectively $(P<0.05$; Table 2$)$.

Though a trend was present, the difference between treatment means for risk of a preweaning treatment event (51.9\% treated vs. $59.6 \%$ treated in MC and CR groups, respectively), did not achieve statistical significance $(P=0.155$; Table 2$)$. Similarly, though a trend was present, the survival distribution functions indicated that calves fed CR did not experience a significantly different risk for preweaning treatment (hazard ratio $=1.22 ; P=0.16$; Figure 1 ).

The risk for a preweaning death event was no different $(P=0.43)$ for calves in the MC group (10.0\% died) vs. calves in the CR group (12.4\% died; Table 2 ). Also, the survival distribution functions indicated that calves fed CR did not experience a significantly different risk for a preweaning death event (hazard ratio $=1.26 ; P=$ 0.43 ) as compared with calves fed MC (Figure 2).

Mean $( \pm$ SD) total days treated was not significantly different for MC calves ( $1.7 \pm 2.3 \mathrm{~d})$ vs. CR calves (2.0 $\pm 2.5 \mathrm{~d})$. Similarly, mean ( \pm SD) treatment costs were not significantly different for all MC calves (10.84 \pm $12.55 \$ /$ calf $)$ than for all CR calves (11.88 $\pm 12.60 \$ /$ calf; $P>0.05$; Table 2).

When evaluating the relationship between serum TP (dependent variable) and serum IgG (explanatory variable), it was found that there was no significant interaction present between serum IgG $\times$ colostrum treatment group $(P>0.05)$. Nonetheless, for the interest of the reader, the data set was stratified by colostrum treatment group and the results presented below.

When considering only MC-fed calves, the regression equation produced to predict serum TP was:

$$
\begin{aligned}
& \text { Serum TP }(\mathrm{g} / \mathrm{dL})=4.2100+0.08429 \\
& \times(\text { serum } \mathrm{IgG})\left(\mathrm{r}^{2}=0.85 ; P<0.0001\right) .
\end{aligned}
$$

Using this equation, a serum IgG of $10.0 \mathrm{mg} / \mathrm{mL}$ (cutpoint for successful passive transfer) would be associated with a serum TP value of $5.05 \mathrm{~g} / \mathrm{dL}$ (Figure 3).

When considering only CR-fed calves, the regression equation produced to predict serum TP was

$$
\begin{aligned}
& \text { Serum TP }(\mathrm{g} / \mathrm{dL})=4.0108+0.09703 \\
& \times(\text { serum } \mathrm{IgG})\left(\mathrm{r}^{2}=0.60 ; P<0.0001\right) .
\end{aligned}
$$

Using this equation, a serum IgG of $10.0 \mathrm{mg} / \mathrm{mL}$ would be associated with a serum TP value of $4.98 \mathrm{~g} /$ dL (Figure 4).

\section{DISCUSSION}

The current study provides producers an opportunity to evaluate the performance of 2 colostrum feeding programs (commercial CR vs. MC) as they were implemented on commercial dairy farms. The study participants included 12 commercial dairies so as to fairly represent a variety of management conditions across the industry. An additional strength, the study included a large enough sample size to allow us to begin to evaluate the effect of feeding a CR product on short- and long-term calf health and economic outcomes. One limitation of the study was that the dams were not tested for infection with MAP. Although in utero transmission of MAP has been reported to occur in a small proportion of subclinically infected cows, this is not a concern for 


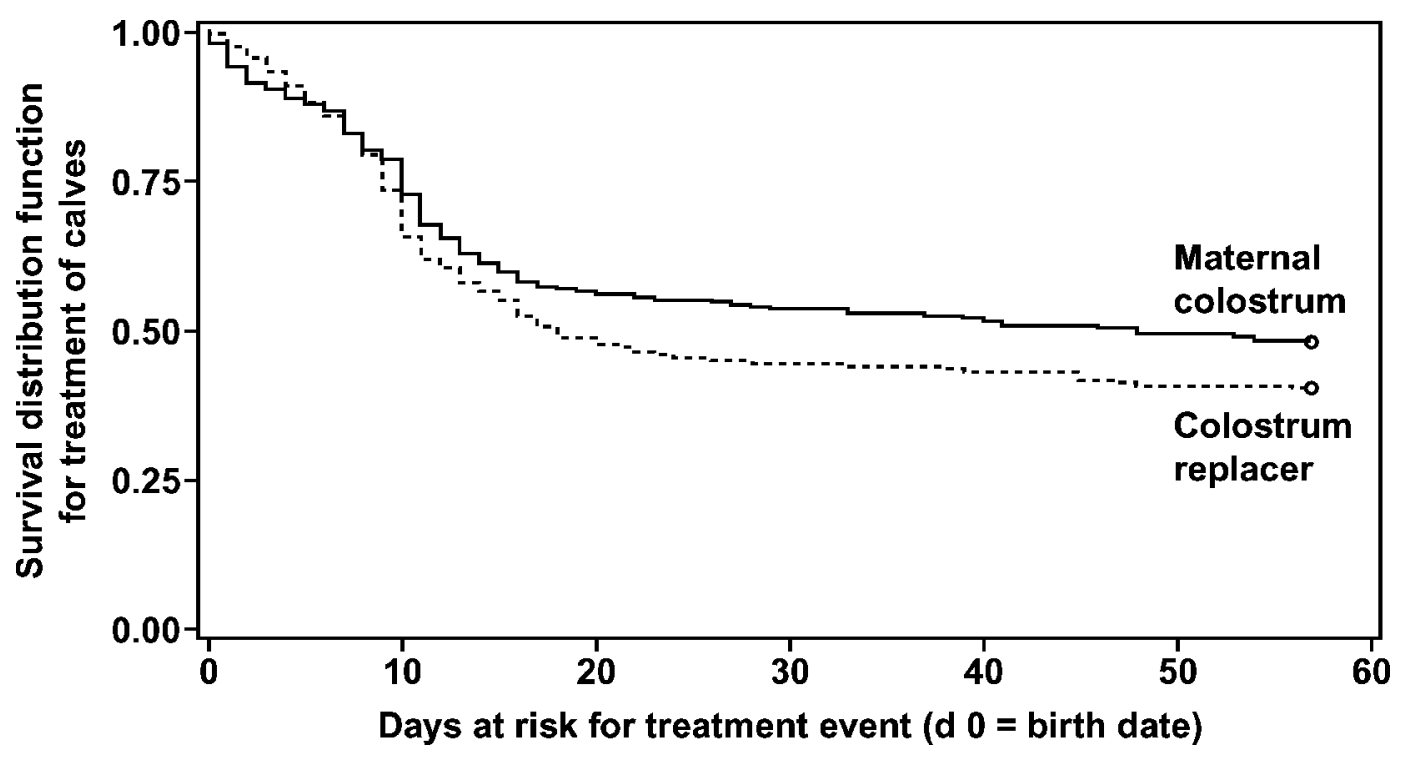

Figure 1. Survival distribution function describing preweaning risk for treatment in calves fed maternal colostrum or a colostrum replacer.

the current study as any in-utero infected calves would have had an equal chance of being assigned to either colostrum treatment group. Thus, the possibility of in utero infections should not introduce a bias into the long-term objective of this study, that being to compare the risk of feeding $\mathrm{MC}$ vs. CR colostrum on risk for Johne's transmission in adult dairy cattle. Another possible limitation of the study was that, given that farm staff on the 12 dairies were doing the work of enrolling calves, it was not possible to collect a precolostral blood sample to measure serum IgG concentrations for the purpose of ensuring that calves had not suckled prior to enrollment and colostrum feeding. If some calves did have an opportunity to suckle, prior to enrollment, then the likelihood of this happening should have been equal for calves in either colostrum treatment group, and would be expected to increase the final serum IgG concentrations measured in both groups. That said, most

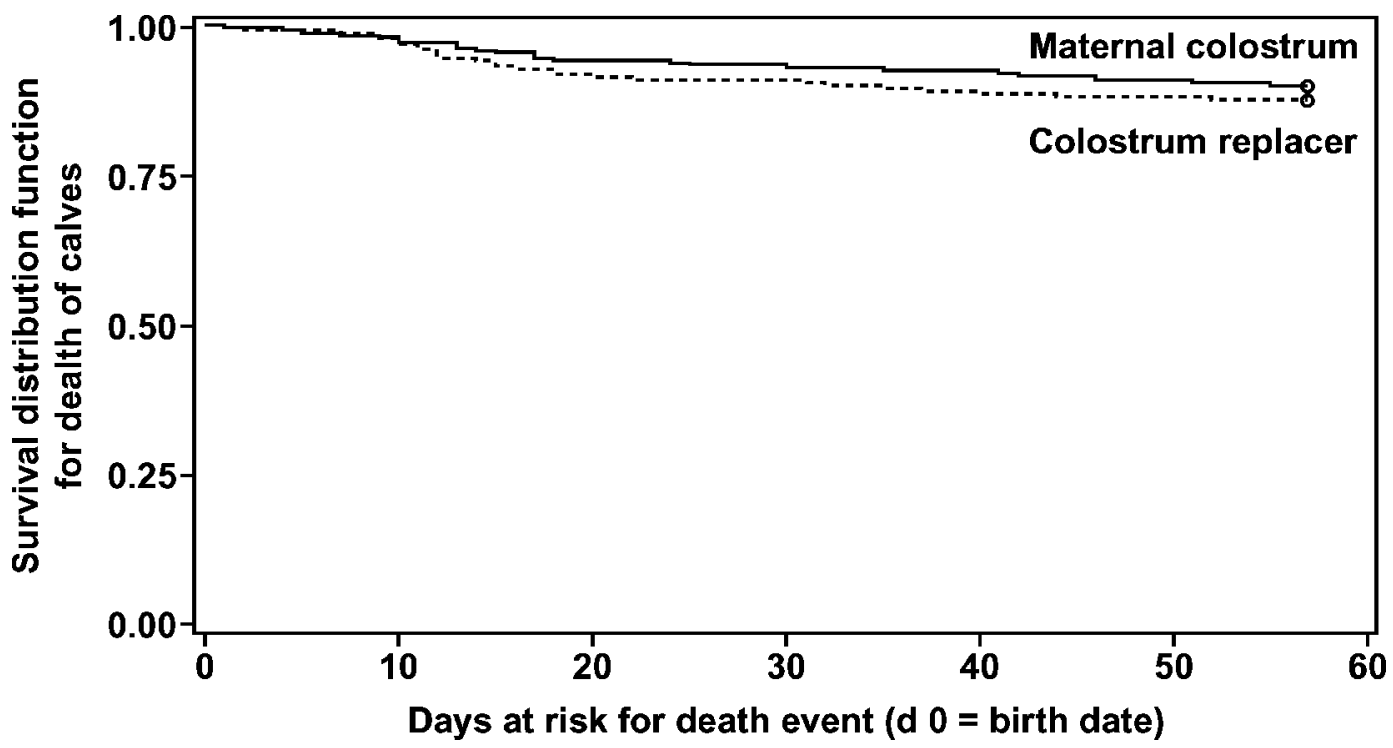

Figure 2. Survival distribution function describing preweaning risk for death in calves fed maternal colostrum or a colostrum replacer. 


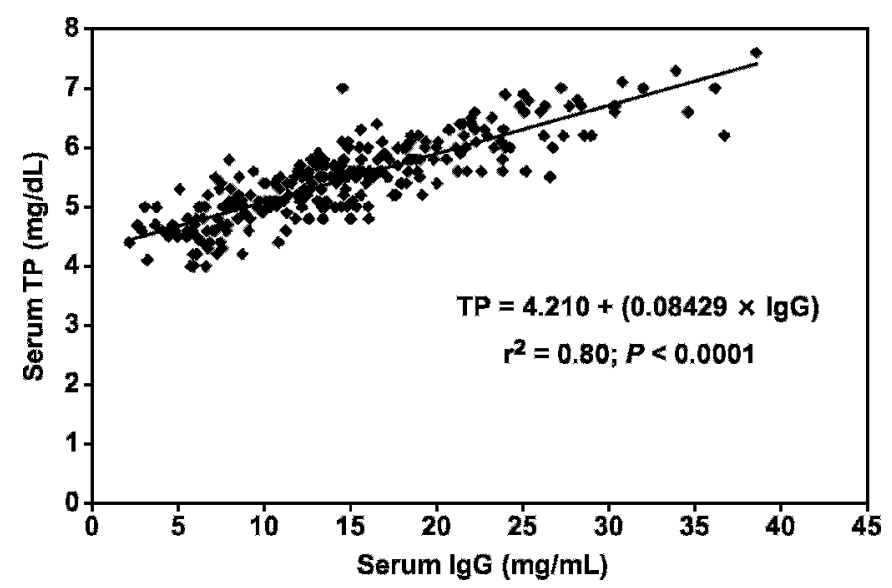

Figure 3. Relationship between serum total protein (TP) and serum IgG for calves fed maternal colostrums.

study herds were moderate-to-large in size, having enough labor for frequent observation of calving facilities. Also study herds reported adhering to the study protocol of removing calves from the dam as soon as possible after birth, and before the calf could suckle. As such, suckling of the dam was likely to be rare, if it occurred at all, and so should have had little effect on study results and inferences. Nonetheless, conclusions drawn from this study should be tempered by the possibility that some CR and MC calves may have had an opportunity to consume some maternal colostrum before being assigned to treatments. Despite these possible limitations, the authors feel that these are outweighed by the strengths: Such multiherd field-based

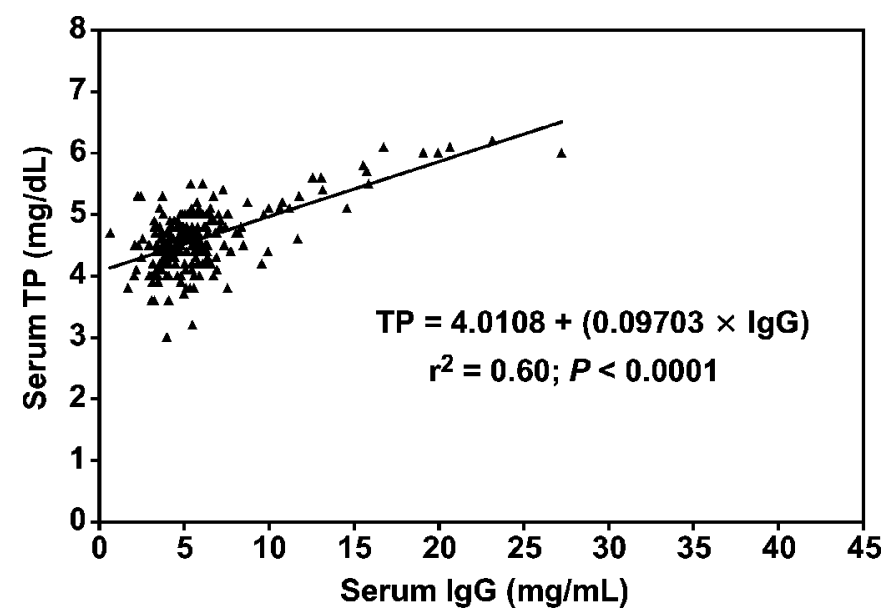

Figure 4. Relationship between serum total protein (TP) and serum IgG for calves fed a plasma-derived commercial colostrum replacement product. studies are necessary to allow producers some insight into the possible health and economic results that may be achieved when using a commercial CR under farmfeeding conditions.

In the current study, we observed significantly lower serum IgG and TP concentrations between 1 to $8 \mathrm{~d}$ of age in CR calves $(\mathrm{IgG}=5.8 \mathrm{mg} / \mathrm{mL} ; \mathrm{TP}=4.6 \mathrm{~g} / \mathrm{dL}$ ), as compared with $\mathrm{MC}$ calves $(\mathrm{IgG}=14.8 \mathrm{mg} / \mathrm{mL} ; \mathrm{TP}=5.5$ $\mathrm{g} / \mathrm{dL}$ ). The FPT rate in this study was 28 and $93 \%$ for $\mathrm{MC}$ and CR calves, respectively. One obvious explanation for this treatment effect was the large difference in IgG mass administered to the calf at first feeding: Calves fed MC received an average dose of $291.5 \mathrm{~g}$ of IgG in $3.8 \mathrm{~L}$ of $\mathrm{MC}$ at the first feeding. By comparison, on the 5 study farms that routinely fed only one colostrum feeding, the CR calves were fed $125 \mathrm{~g}$ of IgG in one dose of CR. For the 7 study farms that routinely provided 2 colostrum feedings, the CR calves were fed a total of $170 \mathrm{~g}$ of IgG over 2 feedings ( 1 dose of CR containing $125 \mathrm{~g}$ of IgG at the first feeding plus one dose of CS containing $45 \mathrm{~g}$ of IgG at the second feeding). This difference in IgG doses between $\mathrm{CR}$ and MC groups reflects normal current practices for MC or CR feeding programs as they would be implemented on commercial dairy operations. It was interesting that serum IgG concentrations were not different, within either colostrum treatment group, for herds feeding only one colostrum feeding vs. for herds feeding 2 colostrum feedings. It was also interesting to note that the day of blood sample collection (1 to 8) was not associated with serum IgG or serum TP measures. These results were expected, as it has been reported elsewhere that herd based testing for passive transfer can be accurately applied to calves up to $1 \mathrm{wk}$ of age (McGuirk and Collins, 2004).

The results of this study are similar to some other studies that have also reported FPT in calves fed a plasma-derived CR containing $\geq 100 \mathrm{~g} / \mathrm{dose}$ of IgG (Quigley et al., 2001), but also differ from some studies that reported attaining acceptable serum IgG levels $(\geq 10.0$ $\mathrm{mg} / \mathrm{mL}$ ) in calves fed $\geq 100 \mathrm{~g}$ in a plasma-derived CR (Jones et al., 2004). In one experiment, 14 calves were fed $100 \mathrm{~g}$ of IgG in one $454 \mathrm{~g}$ dose of 1 of 2 different plasma-derived CR formulations (CR-1 and CR-2). The mean serum IgG concentration at $24 \mathrm{~h}$ was $7.64 \mathrm{mg} /$ $\mathrm{mL}$ (CR-1) and $5.59 \mathrm{mg} / \mathrm{mL}$ (CR-2; Quigley et al., 2001). In a second experiment that fed 2 different plasmaderived CR formulations (CR-3 and CR-4) that provided $122 \mathrm{~g}$ of IgG per dose, mean serum IgG concentrations at $24 \mathrm{~h}$ reached $10.1 \mathrm{mg} / \mathrm{mL}(\mathrm{CR}-4)$ and $11.2 \mathrm{mg} / \mathrm{mL}$ (CR-3), respectively. When 2 doses of CR-3 and CR-4 were fed, providing calves with a total of $244 \mathrm{~g}$ of $\mathrm{IgG}$, mean 24-h serum IgG concentrations reached 13.0 (CR3) and 14.1 (CR-4) $\mathrm{mg} / \mathrm{mL}$. Therefore, Quigley sug- 
gested feeding higher doses of CR, thereby increasing the IgG intake and improving the 24 -h serum IgG concentrations of calves. None of these aforementioned previous studies were performed using the commercially available CR product but rather used purified Ig concentrate. Possible explanations for differences between our study results and these other studies could include differences in Ig mass provided or differences in efficiency of absorption for the Ig concentrate fed among the various studies. The latter hypothesis requires further study. Because calf birth weights could not be consistently recorded on most of the study farms, we could not calculate and report the apparent efficiency of IgG absorption for this study.

Jones et al. (2004) reported there was no difference in serum IgG concentrations at $24 \mathrm{~h}$ in calves fed MC $(13.78 \pm 0.39 \mathrm{mg} / \mathrm{mL})$ vs. in calves fed the same commercially available plasma-derived $\mathrm{CR}$ product (13.96 \pm $0.38 \mathrm{mg} / \mathrm{mL}$; Acquire, APC, Ames, IA) that was used in our study. However, in the Jones et al. (2004) study, the CR calves were fed 2 doses of the CR product in 2 feedings (total dose $=249 \mathrm{~g}$ of IgG for Holsteins or 186 $\mathrm{g}$ of IgG for Jerseys). Furthermore, that study restricted MC intake to $1.42 \mathrm{~L}$ (Holsteins) or $1.06 \mathrm{~L}$ (Jerseys) per feeding so as to ensure that equal doses of IgG were fed to calves in both the MC and CR treatment groups. Conversely, the industry recommended practice for feeding $\mathrm{MC}$ is to feed 12 to $15 \%$ of $\mathrm{BW}$ (3.8 L for a 41 $\mathrm{kg}$ calf) in the first feeding (Davis and Drackley, 1998).

The results of the current study also differ from an earlier study by Quigley et al. (2002) where it was reported that 16 calves fed a plasma-derived CR achieved mean serum IgG and TP concentrations of $13.6 \mathrm{mg} / \mathrm{mL}$ and $4.98 \mathrm{~g} / \mathrm{dL}$, respectively. However, in that study, the CR calves were also fed a higher dose of IgG, as a total of $187 \mathrm{~g}$ of IgG were provided in two feedings at 1 and $8 \mathrm{~h}$ of age.

More recently a study reported that acceptable passive transfer was achieved in 81 and $90 \%$ of calves fed 1 dose (100 g of IgG) or 2 doses (200 g of IgG) of a commercially available colostrum-derived product, respectively (Land O'Lakes Colostrum Replacement, Land O'Lakes Inc., St. Paul, MN; Foster et al., 2006). Mean $( \pm \mathrm{SD})$ serum IgG for the 1 dose or 2 dose groups in that study were $11.6 \pm 2.9 \mathrm{mg} / \mathrm{mL}$ and $16.9( \pm 6.2)$ $\mathrm{mg} / \mathrm{mL}$, respectively. The same study reported that only $10 \%$ of calves achieved successful passive transfer (mean serum $\operatorname{IgG}=7.0 \pm 2.2 \mathrm{mg} / \mathrm{mL}$ ) when calves were fed 2 packs (100 g of IgG) of a different commercially available colostrum-derived CR product (Immu-Start 50, Imu-Tek Animal Health Inc., Fort Collins, CO). Again, possible explanations for differences among the 3 CR-treatment groups examined in the Foster et al. (2006) study and our own study could include differ- ences in dose of IgG fed, differences in efficiency of IgG absorption, or both.

Because the current study was performed on 12 different farms, most without scales to measure birth weight, it was impossible to calculate the apparent efficiency of absorption (\%) of IgG for individual study calves. However, by using the known mean calf serum IgG concentrations $(\mathrm{CR}=5.8 \mathrm{mg} / \mathrm{mL} ; \mathrm{MC}=14.8 \mathrm{mg} / \mathrm{mL}$; Table 2), the known mean colostrum IgG concentrations ( $\mathrm{MC}=76.7 \mathrm{mg} / \mathrm{mL}$; Table 1), an assumed 38.6-kg birth weight for all heifer calves enrolled, and assuming a plasma volume of $9.9 \%$ of birth weight (Quigley et al., 2002), we were able to crudely approximate that the apparent efficiency of absorption of IgG in calves fed MC or CR was 19.6 and $17.9 \%$, respectively.

Taken together, the results of all of these CR studies seem to suggest that higher serum IgG levels and acceptable passive transfer (serum IgG $>10.0 \mathrm{mg} / \mathrm{mL}$ ) is more likely to be attained when higher doses of IgG are fed.

Although the CR-fed calves in the current study experienced a high rate of FPT, it is important to note that there was no statistically significant effect of treatment on preweaning mortality or treatment risk (although a weak trend existed for increased risk of treatment in the CR group). Similarly, there was no effect of treatment on number of days treated or preweaning treatment costs. One possible explanation for these results is that the $\mathrm{CR}$ product provided at least similar immune protection (gut level or systemic), compared with calves in the MC group, for calves on these study farms. Another hypothesis that could have played a role is that calves fed the CR were exposed to fewer bacteria in the first colostrum feeding than were calves fed raw MC, resulting in reduced pathogen exposure. This hypothesis cannot be explored in the current study because colostral bacterial culture results were not available for calves in the CR group. Finally, the reader must remember that whether a calf suffers from illness or death is ultimately a function of the balance achieved between immune status and pathogen exposure from the calf's environment. Immune status will be affected by not only colostrum management, but also by other important calf management factors including nutritional management and environmental or management-related stressors. Factors affecting the level of pathogen exposure will include such variables as calf housing, ventilation, sanitation, and types of pathogens found on the farm. This balance explains why calves with acceptable passive transfer are not always guaranteed of remaining healthy, just as calves with FPT do not always experience higher rates of illness or death (Davis and Drackley, 1998). The authors feel that the 12 herds participating in this study did represent a wide 
range of sanitation, housing, and general management conditions that are frequently observed across the dairy industry. However, it is possible that different health outcomes could be observed in CR and MC-fed calves on farms with different (higher or lower) levels of pathogen challenge; different seasonal, nutritional, or other management conditions than were encountered in this study; or both.

It is currently recommended that serum TP values between 5.0 and $5.2 \mathrm{~g} / \mathrm{dL}$ are the most accurate cutpoints to use to predict a serum IgG value of $10.0 \mathrm{mg} /$ $\mathrm{mL}$ in calves fed MC (Calloway et al., 2002). Though not the major objective of this study, it was interesting to note that the authors did not observe a different relationship between serum IgG and serum TP values in CR-fed calves vs. MC-fed calves. The regression equations produced in this study indicated that, for both treatment groups, a serum TP cutpoint of $5.0 \mathrm{~g} / \mathrm{dL}$ would predict a serum IgG value of $10.0 \mathrm{mg} / \mathrm{mL}$. These findings differ from an earlier study proposing that, due to differences in nonimmunoglobulin protein fractions between $\mathrm{CR}$ and $\mathrm{MC}$, the prediction of plasma IgG concentration using total plasma protein may be inappropriate when calves are fed CR (Quigley et al., 2002). The latter study suggested that, when a plasma-derived $\mathrm{CR}$ is fed, a more appropriate serum TP concentration indicating acceptable PT is $4.85 \mathrm{~g} / \mathrm{dL}$. Possible explanations for the different results observed between these 2 studies could include the fact that different CR formulations were fed in the 2 studies. Specifically, the Quigley et al. (2002) study fed a purified Ig concentrate, whereas our study fed a commercially available CR formulation. Other differences that may/may not have contributed to differences in the apparent relationship between serum TP and IgG could include the timing of blood sample collection (samples collected at $24 \mathrm{~h}$ of age in the Quigley et al. (2002) study vs. between 1 to $8 \mathrm{~d}$ of age in the current study) and possible differences in the serum TP or IgG assays, or both, used between the studies.

\section{CONCLUSIONS}

Calves fed a commercially available plasma-derived CR product had significantly lower serum IgG and serum TP measures between 1 to $8 \mathrm{~d}$ of age than calves fed current industry-recommended volumes of MC. This difference was attributed to a large difference in total mass of IgG consumed between the 2 colostrum feeding groups. Feeding $125 \mathrm{~g}$ of Ig in one dose of a commercial CR product was not sufficient to achieve acceptable passive transfer of IgG in over $90 \%$ of CR calves. However, preweaning treatment risk, days treated, treatment costs, and mortality risk were not different be- tween calves fed MC vs. CR. Mean serum protein concentration indicative of successful passive transfer was $5.0 \mathrm{~g} / \mathrm{dL}$ in calves fed MC or CR. Conclusions drawn from this study should be tempered by the possibility that some CR and MC calves may have had an opportunity to consume some maternal colostrum before being assigned to treatments. Long-term follow up of these calves (to $5 \mathrm{yr}$ of age) is ongoing to describe long-term effects of feeding CR on longevity, productivity, transmission of MAP and other infectious diseases, and economics.

\section{ACKNOWLEDGMENTS}

This study was funded by the Minnesota Rapid Agricultural Response Fund. The commercial CR product used in the study was donated by American Protein Corporation Inc. (Ames, IA). We would like to thank Tristan Malmedal and James Gerdes for their technical assistance visiting farms, and we thank the 12 commercial dairy farms and 2 professional dairy heifer grower operations that helped to make this project possible.

\section{REFERENCES}

Calloway, D. C., J. W. Tyler, R. K. Tessman, D. Hostetler, and J. Hollie. 2002. Comparison of refractometers and test endpoints in the measurement of serum protein concentration to assess passive transfer status in calves. J. Am. Vet. Med. Assoc. 221:1605-1608.

Davis, C. L., and J. K. Drackley. 1998. The Development, Nutrition, and Management of the Young Calf. Iowa State Univ. Press, Ames, IA.

DeNise, S. K., J. D. Robison, G. H. Stott, and D. V. Armstrong. 1989. Effects of passive immunity on subsequent production in dairy heifers. J. Dairy Sci. 72:552-554.

Etzel, L. R., R. E. Strohbehn, and J. K. McVicker. 1997. Development of an automated turbidometric immunoassay for quantification of bovine serum immunoglobulin G. Am. J. Vet. Res. 48:1201-1205.

Faber, S. N., N. E. Faber, T. C. McCauley, and R. L. Ax. 2005. Effects of colostrum ingestion on lactational performance. Prof. Anim. Sci. 21:420-425.

Foster, D. M., G. W. Smith, T. R. Sanner, and G. V. Busso. 2006. Serum IgG and total protein concentrations in dairy calves fed two colostrum replacement products. J. Am. Vet. Med. Assoc. 229:1282-1285.

Jones, C. M., R. E. James, J. D. Quigley III, and M. L. McGilliard. 2004. Influence of pooled colostrum or colostrum replacement on IgG and evaluation of animal plasma in milk replacer. J. Dairy Sci. 87:1806-1814.

Le Jan, C. 1996. Cellular components of mammary secretions and neonatal immunity: A review. Vet. Res. 27:403-417.

McGuirk, S., and M. Collins. 2004. Managing the production, storage and delivery of colostrum. Vet. Clin. North Am. Food Anim. Pract. 20:593-603.

McVicker, J. K., G. C. Rouse, M. A. Fowler, B. H. Perry, B. L. Miller, and T. E. Johnson. 2002. Evaluation of a lateral-flow immunoassay for use in monitoring passive transfer of immunoglobulins in calves. Am. J. Vet. Res. 63:247-250.

NAHMS. 1993. Transfer of maternal immunity to calves. USDA:APHIS:VS, Fort Collins, CO.

Quigley, J. D., III, C. J. Kost, and T. M. Wolfe. 2002. Absorption of protein and IgG in calves fed a colostrum supplement or replacer. J. Dairy Sci. 85:1243-1248.

Quigley, J. D., III, R. E. Strohbehn, C. J. Kost, and M. M. O'Brien. 2001. Formulation of colostrum supplements, colostrums re- 
placers and acquisition of passive immunity in neonatal calves. J. Dairy Sci. 84:2059-2065.

Reiter, B. 1977. Review of nonspecific antimicrobial factors in colostrum. Ann. Rech. Vet. 9:205-224.

Stabel, J. R., and J. P. Bannantine. 2005. Development of a nested PCR method targeting a unique multicopy element, ISMap02, for detection of Mycobacterium avium subsp. paratuberculosis in fecal samples. J. Clin. Microbiol. 43:4744-4750.
Stewart, S., S. Godden, R. Bey, P. Rapnicki, J. Fetrow, R. Farnsworth, M. Scanlon, Y. Arnold, L. Clow, K. Mueller, and C. Ferrouillet. 2005. Preventing bacterial contamination and proliferation during the harvest, storage, and feeding of fresh bovine colostrum. J. Dairy Sci. 88:2571-2578.

Streeter, R. N., G. F. Hoffsis, S. Bech-Nielsen, W. P. Shulaw, and D. M. Rings. 1995. Isolation of Mycobacterium paratuberculosis from colostrum and milk of subclinically infected cows. Am. J. Vet. Res. 56:1322-1324. 